\title{
Changes in SPME-extracted volatile compounds from Iberian ham during ripening
}

\author{
By Ángela Jurado, ${ }^{a *}$ Ana I. Carrapiso, ${ }^{b}$ Jesús Ventanas ${ }^{a}$ and Carmen García ${ }^{a}$
}

\author{
a Tecnología de Alimentos, Facultad de Veterinaria, Universidad de Extremadura, \\ Av Universidad s/n, 10071 Cáceres, Spain. \\ b Tecnología de Alimentos, Escuela de Ingenierías Agrarias, \\ Universidad de Extremadura, Crta Cáceres s/n, 06071 Badajoz, Spain. \\ ( ${ }^{\star}$ Corresponding author: ajuradog@unex.es)
}

\section{RESUMEN}

Cambios de compuestos volátiles extraídos por SPME en jamones lbéricos durante la curación.

Un procedimiento de microextración en fase sólida (SPME) en espacio de cabeza fue ensayado para estudiar la evolución de los compuestos volátiles durante la curación de Jamones lbéricos de cerdos criados en régimen de montanera (en libertad, con bellotas y pasto disponible) y un sistema OH-Pienso (estabulados, con un pienso alto en ácido oléico). El efecto del tiempo de curación en los compuestos volátiles fue más marcado que el efecto de la alimentación. La mayoría de los compuestos volátiles afectados por el tiempo de curación fueron compuestos que proceden de la reacción de Strecker y Maillard, que se incrementaron significativamente $(p<0.05)$ durante el tiempo de curación. Esta tendencia fue clara para los compuestos volátiles: 2-metilpropanal, 2-metilbutanal, 2-metil-1-butanol, disulfuro de dimetilo, 2,6.dimetilpiracina + dihidro-2(3H)furanona y bencenometanol $y$, por tanto ellos podrían ser usados como indicadores del tiempo de maduración. Por el contrario, algunos compuestos derivados de la oxidación lipídica disminuyeron significativamente durante el procesado del jamón. El sistema de alimentación tuvo un ligero efecto en los compuestos volátiles, aunque fue significativo para algunos compuestos $(p<0.05)$. Algunos de ellos (ácido butanoico, 2,6dimetilpiracina y 1-octen-3-ol) fueron más abundantes en jamones de Montanera que en jamones de Pienso. Estas pequeñas diferencias podrían ser importantes porque los compuestos involucrados han sido identificados como aromas del jamón Ibérico.

PALABRAS CLAVES: Compuestos volátiles - Jamón Ibérico - Microextracción en fase sólida - Sistema de alimentación - SPME - Tiempo de curación.

\section{SUMMARY}

Changes in SPME-extracted volatile compounds from Iberian ham during ripening.

A headspace SPME procedure was tested to study the evolution of volatile compounds during the ripening of Iberian hams from pigs reared in a Montanera system (outdoorbased, with acorn and pasture available) and a HO-Pienso system (indoor-based, with a high oleic acid concentrate). The effect of the ripening time on volatile compounds was more marked than the effect of feeding system. Most volatile compounds affected by the ripening time were compounds that come from Strecker and Maillard reactions, which increased significantly $(p<0.05)$ during the ripening time. This trend was clear for the volatile compounds 2methylpropanal, 2-methylbutanal, 2-methy-I-butanol, disulfide dimethyl, 2,6-dimethylpyrazine + dihidro-2 $(3 \mathrm{H})$ furanone and benzenemethanol and, therefore they could be used as indicators of the ripening time. Conversely, some of the lipid oxidation-derived compounds decreased significantly throughout ham processing. Feeding system had a weak effect on volatile compounds, but it was significant for some compounds $(p<0.05)$. Some of them (butanoic acid, 2,6dimethylpirazyne and 1-octen-3-ol) were more abundant in Montanera than in Pienso hams. These small differences could be important because they involve compounds that have been identified as Iberian ham odorants.

KEY-WORDS: Feeding system - Iberian ham - Ripening time - Solid-phase microextraction - SPME - Volatile compounds.

\section{INTRODUCTION}

Dry-cured Iberian ham is a product of great importance in Spain. Its typical flavour is an outstanding quality parameter and a major contributor to consumer acceptance (Ruiz et al., 2002). Iberian ham sensory quality depends on raw meat characteristics, which are mainly influenced by genetic factors (Carrapiso et al., 2003a; Carrapiso and García, 2008), rearing system (Cava et al 2000a; Carrapiso et al., 2003a), concentrate feeding composition (Ruiz et al., 2005: Ventanas et al., 2007; Jurado et al., in press), montanera feeding period length (Carrapiso et al., 2007), but also by processing conditions (Andrés et al., 2004). Therefore, there are a lot of relevant factors that influence Iberian ham sensory characteristics, and that causes a great heterongenety in the Iberian ham quality.

Currently the quality control is perfomed in raw meat but barely during Iberian ham process: the only compulsory control is a minimum ripening time (500 or 660 days according to the pieces weight) (RD 1469/2007). Ripening conditions and time are essential for flavour development, and in fact it has been demonstrated that ripening time affects flavour sensory traits: hams with longer ripening 
times show higher odour and flavour features and lower rancidity values than hams with shorter ripening times (Ruiz et al., 1999).

Volatile compounds are the main contributors to flavour of meat products (Motram, 1998), and they are generated through the chemical reactions (lipid autooxidation, Strecker and Maillard reactions) which take place throughout Iberian ham ripening (García et al., 1991). Therefore, volatile compounds could be suitable to estimate the flavor features, and therefore Iberian ham quality. By knowing the volatile compound profile, it would be possible to predict the current ripening time or if the pieces have been ripened for the minimum required ripening time. In addition, they could allow estimate the feeding system used to fatten the animals.

Solid phase microextraction (SPME) is an effective tool for analysing the volatile compounds. This technique is sensitive, selective, fast, low-cost, solvent free, easy to handle and also compatible with low detection limits. In addition, as a low extraction temperature can be used, SPME could give a better estimation of the aroma profile as it is perceived by the human nose (reviewed by Kataoka et al., 2000; Brunton et al., 2000). SPME has been widely used to extract volatile compounds in several foods and drinks (Chin et al., 1996; Elmore et al, 1997; Bazemore et al., 1999; Marsili, 1999) and also in dry-cured ham (Gianelli et al., 2002; GarcíaEsteban et al., 2004) and Iberian ham (Ruiz et al., 1998, 2001; Andres et al., 2002; Ramirez and Cava, 2007).

Andrés et al. (2002, 2007) investigated the changes in the volatile compounds of Iberian ham during ripening by using a direct-extraction device for the SPME extraction, showing large fluctuations in the volatile compound abundances. Although the procedure has the unquestionable advantage of being minimally destructive, it does not provide an accurate control of the temperature during the volatile compound extraction. The SPME-extraction is greatly influenced by temperature (Prosen and Zupancic-Krajl 1999; Kataoka et al., 2000). The aim of this study was to research the changes during ripening in the volatile compounds extracted by using a conventional SPME procedure that provides an accurate control of the extraction conditions, and to propose volatile compounds that could be used as indicators of the flavour development throughout processing or the feeding system.

\section{MATERIALS AND METHODS}

\subsection{Raw Iberian hams}

Forty legs were obtained from Iberian pigs reared in cofinement on a high oleic acid concentrate (Pienso hams) (for details on composition, see Muriel et al., 2002). Other forty legs were obtained from Iberian pigs reared in a free-range system during the fattening period (75 days before slaughter), the only fed source being acorn and pasture (Montanera hams). All the animals were slaughtered at about 145 $\pm 10 \mathrm{Kg}$ (mean \pm standard deviation).

\subsection{Processing of the dry-cured Iberian hams}

The hams were processed in controlled humidity and temperature rooms, first in a local factory (the first 100 days) and then in the Department of Food Science (University of Extremadura) by applying the usual temperature and relative humidity values of the tradicional processing (for details, see Jurado et al., 2007). Conditions applied during Iberian ham ripening are shown in Table 1. The whole process lasted 722 days.

\subsection{Sampling}

The hams were sampled at five different moments of processing: at day 120 (end of postsalting), day 230 (end of the drying stage), day 361 , day 516, and day 722 (end of the first third, the second third and the end of the cellar phase). Five Montanera hams and five Pienso hams were sampled each time, except at the end of processing, when twenty Montanera hams and twenty Pienso hams were sampled.

Samples were obtained by extracting a cilinder (sized $10 \times 2.5 \mathrm{~cm}$ ) using a stainless steel tube with a cutting edge and they mainly included the Semimembranosus and Biceps femoris muscles. Samples were vacumm-packaged and frozen at $-80{ }^{\circ} \mathrm{C}$ until being analysed. Subcutaneous and intermuscular fat were removed just before the analyses.

\subsection{Volatile compound extraction procedure}

A SPME fibre coated with Carboxen-poly

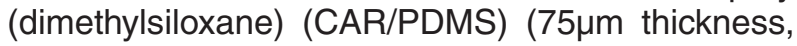

Table 1

Conditions applied during Iberian ham ripening and the five different times of ham sampling

\begin{tabular}{ccccc}
\hline & Temperature & Relative humidity & Days \\
\hline Salting & $2-3^{\circ} \mathrm{C}$ & $95 \%$ & $0-10 / 11(\mathrm{a} \mathrm{day} / \mathrm{kg})$ \\
Postsalting 1 & $2-3^{\circ} \mathrm{C}$ & $85 \%$ & $11-63$ & \\
Postalting 2 & $10^{\circ} \mathrm{C}$ & $75 \%$ & $63-120$ & $121-230$ \\
Drying & from 10 to $30{ }^{\circ} \mathrm{C}$ & from $75 \%$ to $65 \%$ & $231-722$ & Day 120 \\
Cellar & $19{ }^{\circ} \mathrm{C}$ & $70 \%$ & 230 & Days 361,516 and 722 \\
\hline
\end{tabular}


Supelco Co., Bellefonte, U.S.A.) was used to extract the volatiles. This type of fibre was chosen because of its high sensitivity (Brunton et al., 2000) and it has been recommended to extract the dry-cured ham volatile compounds (Gianelli et al., 2002; García-Esteban et al., 2004). Prior to extraction analysis, the SPME fibre was preconditioned at $280^{\circ} \mathrm{C}$ for $45 \mathrm{~min}$ in the GC injection port.

Samples were ground with a commercial grinder. $1 \mathrm{~g}$ was weighted into a $4 \mathrm{ml}$ vial, which was screw-capped with a laminated Teflon-rubber disk. The fibre was inserted into the sample vial through the septum and exposed to headspace for $30 \mathrm{~min}$. The vial was kept in a water bath at $35^{\circ} \mathrm{C}$ during the extraction procedure.

\subsection{Gas chromatography-mass spectrometry}

The SPME fibre was inserted (and maintained during the whole chromatographic run) in the injection port in the splitless mode (at $280{ }^{\circ} \mathrm{C}$ ) of a HP 6890GC series II gas chromatograph (HewlettPackard, U.S.A.) coupled to a mass-selective detector (HP-5973A, Hewlett-Packard, U.S.A.). Volatiles were separated using a HP-5 bondedphase fused-silica capillary column $(5 \%$ phenylmethysilicone, $50 \mathrm{~m} \times 0.32 \mathrm{~mm}$ I.D., film thickness $1.05 \mu \mathrm{m}$, Hewelett-Packard, U.S.A.). The oven temperature program was isothermal for $10 \mathrm{~min}$ at $40{ }^{\circ} \mathrm{C}$, raised to $250{ }^{\circ} \mathrm{C}$ at the rate of $5{ }^{\circ} \mathrm{C} \mathrm{min}{ }^{-1}$, and held for $5 \mathrm{~min}$. The tranfer line to the mass spectrometer was maintained at $280^{\circ} \mathrm{C}$. The mass spectra were obtained by electronic impact at 70 $\mathrm{eV}$, with a multiplier voltage of $1756 \mathrm{~V}$, collecting data at a rate of 1 scan $\mathrm{s}^{-1}$ over the $\mathrm{m} / \mathrm{z}$ range of 30 to 500. $n$-Alkanes (Sigma, Saint Louis MO, USA) were run under the same chromatographic conditions to calculate the Kovats indexes.

Compounds were tentatively identified by comparing mass spectra with those contained in the NIST/EPA/NIH and Wiley libraries and by comparison of the calculated Kovats indexes with those reported in the literature (Kondjoyan and Berdagué, 1996; Elmore et al., 2000; Carrapiso et al., 2003b). Results were expressed as area units $(\mathrm{AU})$.

\subsection{Data analysis}

The effect of processing time $(120,230,361,516$ and 722 days), rearing conditions (Montanera vs Pienso) and the interaction were analysed by using a two-way analysis of variance with interaction by the GLM procedure. When significant differences among the means of each group appeared, they were checked by using the Tukey test. A factor analysis (using principal components analysis as the method for factor extraction) was applied to evaluate the relations between variables (Hair et al., 1998). Statistic analyses were performed by means of the SPSS version 15.0.

\section{RESULTS AND DISCUSSION}

Among the identified compounds $(n=70)$, only those appearing in all the samples of at least one ripening stage were selected to be researched during the ripening. The 36 volatile compounds selected are included in Table 2. Some of them appeared in coelution with another compound: pentanal and heptane, hexanal and octane, 2,6dimethylpyrazine and dihydro 2(3H)-furanone.

All these volatile compounds have been previously identified in fully ripened Iberian ham (García et al., 1991), and previous researches on this product have investigated the effect on them of the rearing system (López et al., 1992; Carrapiso et al., 2002a; Carrapiso et al., 2003b), ripening time (Ruiz et al., 1999; Andrés et al., 2002), the bone taint spoilage of hams (García et al., 2000). Some

Table 2

Selected volatile compounds

\begin{tabular}{lcc}
\hline \multicolumn{1}{c}{ Volatile Compounds } & LRI $^{\text {a }}$ & Origin $^{\text {b }}$ \\
\hline Acetaldehyde & $<500$ & aa \\
Metanethiol & $<500$ & aa \\
2-Propanone & $<500$ & lipids \\
2-Methylpropanal & 547 & aa \\
Acetic acid & 597 & aa $^{\mathrm{c}}$ \\
3-Methylbutanal & 651 & aa \\
2-Methylbutanal & 662 & aa \\
2-Pentanone & 688 & lipids \\
Pentanal & 697 & lipids \\
Heptane & 700 & lipids \\
3-Methyl-1-butanol & 738 & aa \\
2-Methyl-1-butanol & 743 & aa \\
Dimethyl disulfide & 752 & aa \\
1-Pentanol & 770 & lipids \\
Butanoic acid & 781 & aa \\
2,3- Butanodiol & 789 & lipids \\
Octane & 800 & lipids \\
Hexanal & 801 & lipids \\
3-Methylbutanoic acid & 837 & aa \\
1-Hexanol & 869 & lipids \\
2-Heptanone & 888 & lipids \\
Heptanal & 900 & lipids \\
3-Methylthiopropanal & 905 & aa \\
2,6-Dimethylpyrazine & 913 & aa \\
Dihydro 2(3H)-furanone & 914 & aa \\
Benzaldehyde & 968 & aa \\
1-Octen-3-ol & 979 & lipids \\
2-Pentylfuran & 991 & lipids \\
Octanal & 1003 & lipids \\
Benzenemethanol & 1039 & aa \\
Benzeneacetaldehyde & 1052 & aa \\
5-Ethyldihydro-2(3H)-furanone & 1060 & aa \\
1-Octanol & 1068 & lipids \\
Nonanal & 1104 & lipids \\
Benzeneethanol & 1123 & aa \\
5-Butyldihydro-2(3H)-furanone & 1291 & aa \\
\hline
\end{tabular}

${ }^{a} \mathrm{LRI}$ values: linear retention indices on HP-5 capillary column ${ }^{b}$ Origin of volatile compounds (Belitz y Grosh, 1992; Mottram, 1998; Pripis-Nicaulau et al., 2000): aa: volatile compounds coming from amino acids generated through Strecker and Maillard reactions. Lipids: volatile compounds coming from lipid oxidation.

${ }^{c}$ Also generated through lipid oxidation reactions. 
of these compounds contribute to the overall ham flavour as they have been reported as odorant of Iberian hams (Carrapiso et al., 2002b; Carrapiso and García, 2004), and also of other dry-cured hams (Flores et al., 1997; Blank et al., 2001) and meat products (Mottram, 1998; Meynier et al., 1999; Timón et al., 2004).

Among the 36 compounds included in Table 2. 16 of them have been associated with lipid oxidation reactions, and even some of them are lipid oxidation markers (Shahidi et al., 1987; Cava et al., 1999; Shahidi, 2001; O'Sullivan et al., 2003); 15 compounds are generated from amino acids through Strecker and Maillard reactions; and 5 of them could generate through lipid oxidation or Strecker and Maillard reactions (Belitz and Grosh, 1992; Mottram, 1998; Pripis-Nicaulau et al., 2000) (Table 2).

\subsection{Changes throughout Iberian ham processing}

Volatile compound profiles were markedly different throughout processing. At the end of postsalting, (day 120) the most abundant volatile compounds were the coelution of hexanal and octane, 2-propanone, acetic acid, 1-pentanol, nonanal and the coelution of pentanal and heptane. However, in the finished product 3-methylbutanal was the most abundant volatile compound, followed by hexanal and octane, acetic acid, 2-methylbutanal, 2-propanone and 2-methylpropanal. In summary, in the first sampling time (day 120), the compounds from lipid oxidation dominated the volatile compound profile, whereas in the finished product volatile compounds from Strecker reactions (3methylbutanal, 2-methylbutanal, 2-methylpropanal) became the most abundant volatile compounds.

With regard to the quantitative changes in the volatile compounds throughout processing, the SPME-GC-MS procedure allowed to find a significant effect of the ripening time on the total chomatographic area counts. A steady increase of the total area was found from day 120 until day 516, and then a slight but not significant decrease appeared (Table 3). This trend agrees with a previous study focused on the evolution of Iberian ham volatile compounds extracted by using a direct-extraction-SPME method that did not allow an accurate control of temperature extraction (Andrés et al. 2002).

Most volatile compounds (24 of 36) were significantly influenced by the ripening time (Table 3). Most of them are compounds that come from Strecker and Maillard reactions, and only six compounds are generated from lipid oxidation reactions (1-pentanol, 1-hexanol, 2-heptanone, octanal, 1-octanol) (Table 2).

With regard to the Strecker and Maillard volatile compounds, they increased significantly during the ripening time (Table 3 ). There was a marked increase from day 120 to day 230 in these compounds and, in fact, some of these compounds were not detec- ted until day 230 (methanethiol, 2-methylpropanal, dimethyl disulfide, 3-methylthiopropanal, benzenemethanol, benzeneacetaldehyde, 5ethyldihydro-2(3H)-furanone), and even some of them were not detected until day 361 (benzeneethanol and 5-butyldihydro-2(3H)-furanone) (Table 3). The volatile compounds also increased after day 230 , and some of them (2-methylpropanal, 2methylbutanal, 2-methy-l-butanol, disulfide dimethyl, 2,6-dimethylpyrazine + dihidro-2(3H)furanone and benzenemethanol) reached the largest levels at the last stage of processing (Table 3), and therefore they could be used as indicators of the ripening time. By studying these compounds it would be possible to estimate the Iberian ham current ripening time or if the pieces have been ripened for the minimum ripening time established for Iberian hams (RD 1469/2007). It is interesting to take into account the evolution of 2-methylbutanal which should reach values above 1400 UAA in the last stage of processing, because it would indicate a processing longer than 660 days.

On the other hand, these results would reveal a steady development of chemical reactions involved in the generation of Strecker and Maillard derived volatile compounds, including protein degradation, throughout the whole ripening stage, resulting in an increase in these compounds. In a previous study, we demostrated that an increase of free amino acids was followed by the generation of amino acids derived volatile compounds (Jurado et al., 2007).

This trend is in agreement with results by Ruiz et al., (1999), who reported that branched aldehydes (2 and 3-methylbutanal) were more abundant in the more aged Iberian hams. Hinrichsen and Pedersen (1995) have also found that Parma hams with a ripening time of 125 days showed lower levels of 3methylbutanal, 2-methylbutanal, 2-methylpropanal than those with a ripening time of 485 days. However, Andres et al. (2002), who monitored some of the branched aldehydes (2 and 3-methylbutanal) throughout Iberian ham processing by using a direct-extraction-SPME method, did not found a clear pattern in the evolution of these compounds. In the cited study, the extraction of volatile compounds was perfomed at the temperature of the chamber where hams were kept in each processing time, which probably led to obtain more variability in the volatile compounds extraction than in the present study. In fact, for accurate and precise analysis, a control of the extraction temperature is essential (reviewed by Kataoka et al., 2000), and also it has been previously reported when sampling dry cured Iberian ham (Ruiz et al., 1998).

Conversely to the Strecker and Maillard volatile compounds, five compounds derived from lipid oxidation reactions (1-pentanol, 1-hexanol, octanal, 1-octen-3-ol, 1-octanol) decreased significantly during ripening, reaching the lowest levels in the last stage of processing. Only 2-heptanone, also a compound from lipid oxidation, increased during the ripening time (Table 2 ). 


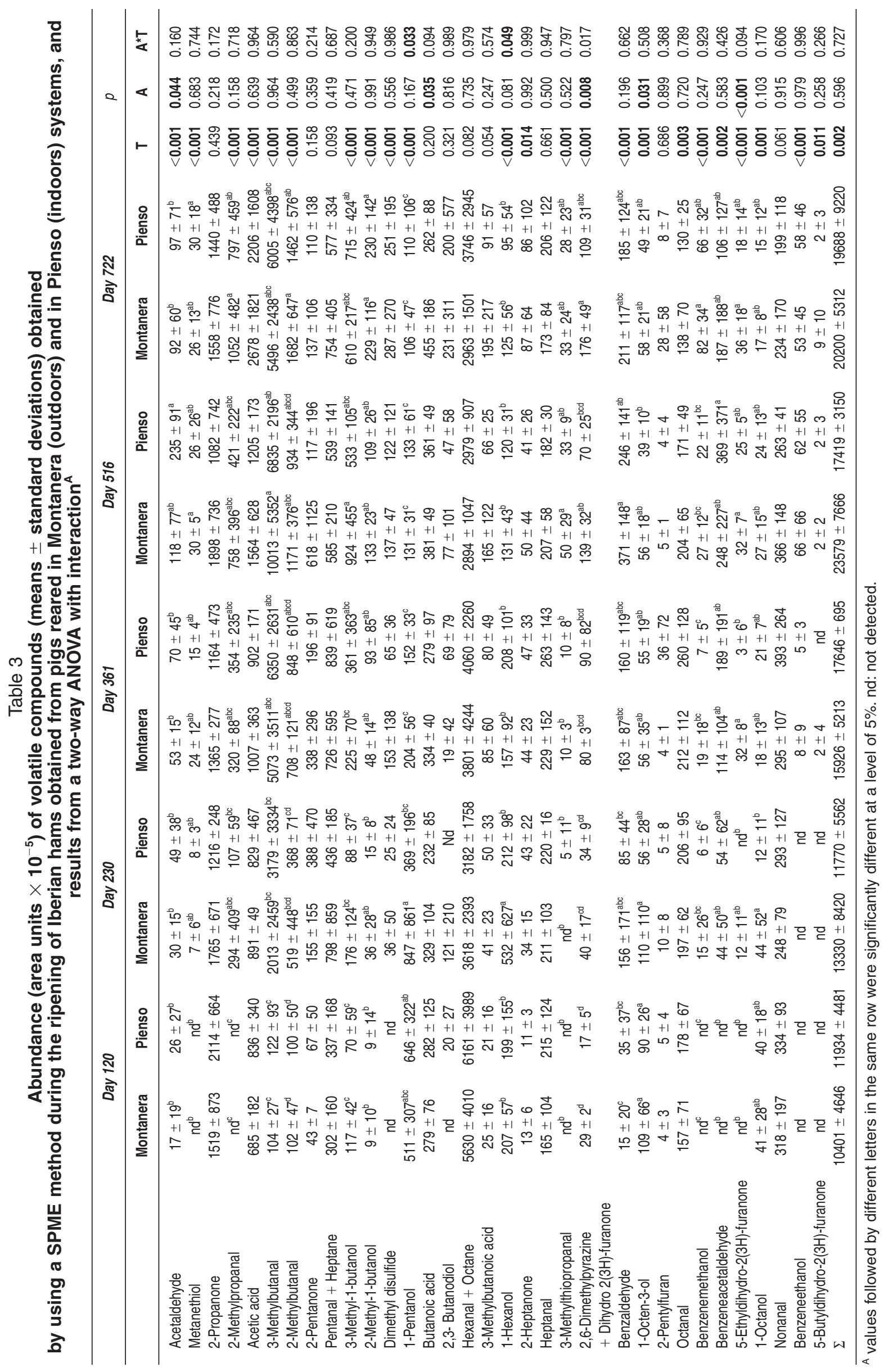


Variantions in the lipid oxidation-derived compounds agree previous researches (Antequera et al., 1992; Jurado et al., 2002): an increase during the first stages and a subsequent decrease during the cellar phase. This decrease in the lipid oxidation-derived compounds could be due to their participation in other chemical reactions yielding other volatile or non volatile compounds and probably to a decrease in the oxidation reactions. Results agree with those by Ruiz et al., (1999) for Iberian ham, who reported a decrease in some lipid oxidation derived compounds from day 420 to day 600 of processing. Also Hinrichsen and Pedersen (1995) found for Parma hams a decrease in hexanal, pentanal and npentanol from day 125 to day 485 of ripening.

A previous study focused on the evolution of Iberian ham volatile compounds extracted by using a direct-extraction-SPME method that did not allow an accurate control of temperature extraction (Andrés et al. 2002), did not show a clear trend in the evolution of lipid oxidation-derived compounds: increases and decreases in theses volatile compounds were observed during Iberian ham processing. In the present study, the extraction was perfomed at controlled temperature (at $35^{\circ} \mathrm{C}$ during the extraction procedure), which has avoided the varibility due to the extraction temperature.

\subsection{Detection of differences caused by the feeding system of pigs}

The effect of the feeding system (Montanera vs HO-Pienso hams) on the volatile compounds was slight but significant for some compounds. No significant effect of the feeding system on lipid oxidation aldehydes (such as hexanal, nonanal, octanal and heptanal) was found (Table 3).

Conversely, a significant effect was observed on six volatile compounds (Table 3 ). Some of them were more abundant in Montanera than in Pienso hams (butanoic acid, 2,6-dimethylpyrazine and 1-octen-3$\mathrm{ol})$, and they have been described as odor-active compounds of dry-cured ham (Blank et al., 2001; Carrapiso et al., 2002b; Flores et al., 1997). Acetaldehyde, which also have been identified as an odorant of Iberian ham (Carrapiso and García, 2007), was also affected by the feeding system, being more abundant in HO-Pienso hams than in Montanera hams. In any case, these small differences could be important because they involve compounds that are Iberian ham odorants, and in fact remarkable differences between the flavour characteristics of these Montanera and HO-Pienso hams were found in the sensory analysis (Jurado et al., in press).

For some compounds results did not match with those of other studies (López et al., 1992; Cava et al., 2000b; Carrapiso et al., 2003b). Differences in results are probably related to the different extraction techniques applied, and to other factors related to raw material (such as concentrate feeding composition, montanera feeding period length) or to the ripening conditions (temperature, relative humidity and ripening time). These factors could cause a great heterogenity in the results.

The weak influence of the feeding system on volatile compounds could be due to the great

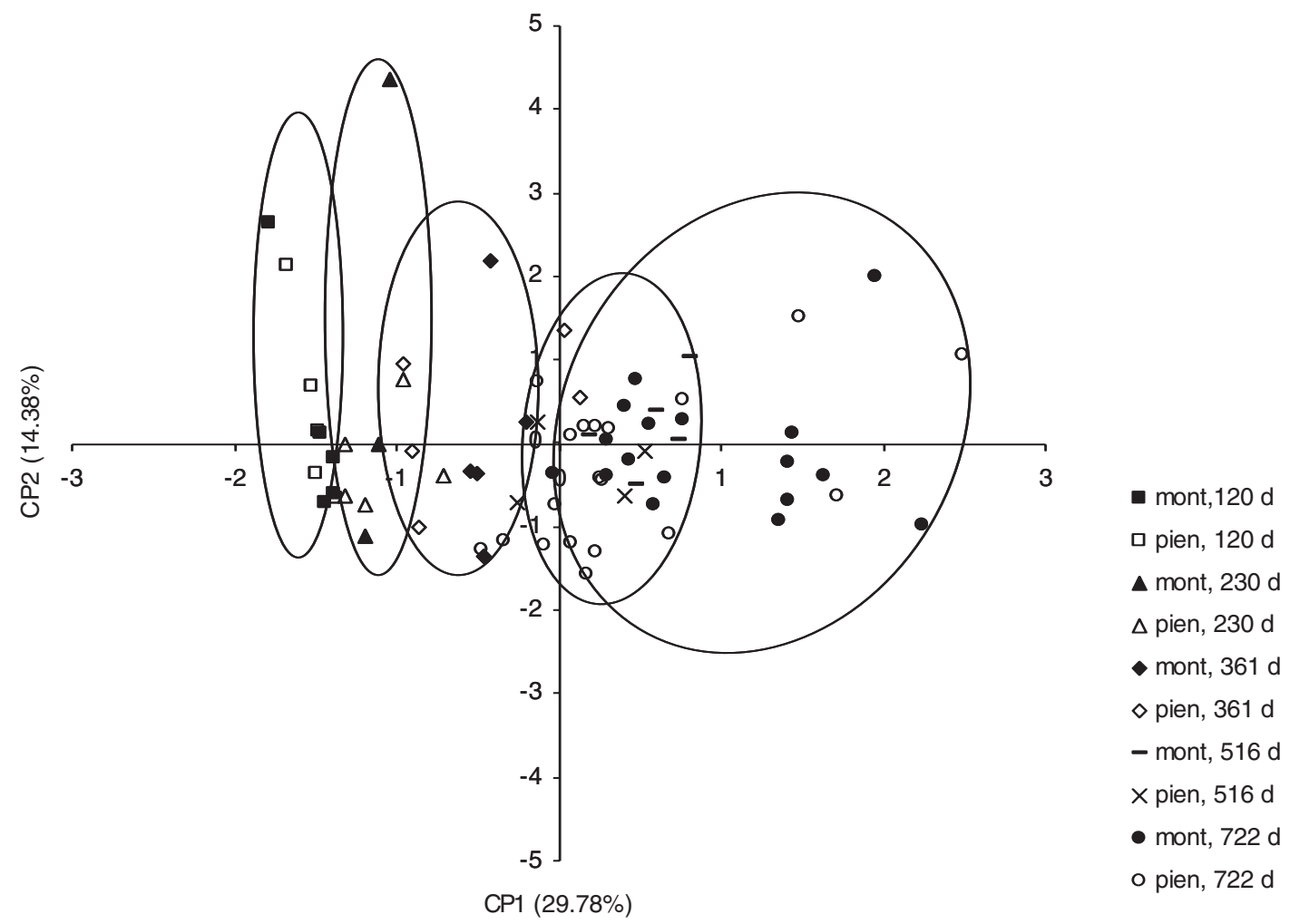

Figure 1.

Projection of the samples onto the space defined by the first two principal components (PC1and PC2) obtained. 
similarity between the fat composition of the feeding used for the pigs reared in the HO-Pienso (a high oleic acid concentrate) and in the Montanera system (grass and acorns), which led to obtain a similar intramuscular fat composition and content in the raw meat (Muriel et al., 2002). Fat content has a marked effect on the release of the volatile compounds from meat products (Chevance and Farmer, 1999; Carrapiso, 2007), and also has an outstanding influence, as their fatty acid profiles does, on the generation of volatile compounds (Mottram, 1998; Elmore et al., 2002; Hidalgo and Zamora, 2004).

\subsection{Principal component analysis}

A principal component analysis was perfomed to study the relationship among samples and among variables. The value for the Kaiser-Meyer-Olkin measure of sampling adequacy was suitable (0.730).

Figure 1 shows the projection of the samples onto the space defined by the two first principal components (PC1 and PC2 accounted for the $46.16 \%$ of the total variability). The PC1 axis was mainly composed of volatile compounds coming from amino acids by means of Maillard and Strecker reactions (coefficients greater than 0.6) (Table 4). All these volatile compounds were placed in the positive zone of the PC1 axis, which indicates a positive relationship among them.

On the other hand, volatile compounds which come from oxidative processes had little loads in the PC1 for most compounds (Table 4). The largest load appeared for 1-pentanol $(-0.513)$, revealing a negative relation between this variable and the volatile compounds coming from Strecker and Maillard reactions.

As it can be observed in the Figure 1, the samples were grouped according to the ripening time in the PC1 axis: 120 days aged samples appear in the negative semi-axis of PC1, which was characterised by low levels of Strecker and Maillard compounds (Table 4), and as the samples had a highest degree of ripening, they were nearest to the positive area of PC1, which was mainly explained by Strecker and Maillard compounds (Table 4). The samples with a ripening time of 516 and 722 days

Table 4

Factor loadings for each volatile compounds on the first two principal components obtained

\begin{tabular}{|c|c|c|}
\hline \multirow[b]{2}{*}{ Compounds } & \multicolumn{2}{|c|}{ Component (\% variance explained) } \\
\hline & CP1 (29.78\%) & CP2 (14.38\%) \\
\hline Acetaldehyde & 0.477 & -0.052 \\
\hline Metanethiol & 0.714 & -0.019 \\
\hline 2-Propanone & -0.005 & 0.010 \\
\hline 2-Methylpropanal & 0.797 & 0.176 \\
\hline Acetic acid & 0.657 & 0.042 \\
\hline 3-Methylbutanal & 0.687 & 0.138 \\
\hline 2-Methylbutanal & 0.880 & 0.138 \\
\hline 2-Pentanone & 0.061 & 0.071 \\
\hline Pentanal + Heptane & 0.339 & 0.623 \\
\hline 3-Methyl-1-butanol & 0.734 & -0.003 \\
\hline 2-Methyl-1-butanol & 0.789 & -0.031 \\
\hline Dimethyl disulfide & 0.688 & 0.055 \\
\hline 1-Pentanol & -0.513 & 0.634 \\
\hline Butanoic acid & 0.486 & 0.242 \\
\hline 2,3- Butanodiol & 0.507 & 0.238 \\
\hline Hexanal + Octane & -0.149 & 0.742 \\
\hline 3-Methylbutanoic acid & 0.472 & 0.098 \\
\hline 1-Hexanol & -0.262 & 0.664 \\
\hline 2-Heptanone & 0.420 & 0.107 \\
\hline Heptanal & -0.001 & 0.769 \\
\hline $\begin{array}{l}\text { 3-Methylthiopropanal } \\
\text { 2,6-Dimethylpyrazine }\end{array}$ & 0.734 & -0.009 \\
\hline + Dihydro 2(3H)-furanone & 0.808 & 0.063 \\
\hline Benzaldehyde & 0.690 & 0.288 \\
\hline 1-Octen-3-ol & -0.250 & 0.809 \\
\hline 2-Pentylfuran & 0.174 & 0.140 \\
\hline Octanal & -0.225 & 0.664 \\
\hline Benzenemethanol & 0.788 & 0.028 \\
\hline Benzeneacetaldehyde & 0.507 & 0.021 \\
\hline 5-Ethyldihydro-2(3H)-furanone & 0.625 & 0.144 \\
\hline 1-Octanol & -0.238 & 0.792 \\
\hline Nonanal & -0.163 & 0.539 \\
\hline Benzeneethanol & 0.598 & -0.098 \\
\hline 5-Butyldihydro-2(3H)-furanone & 0.508 & 0.012 \\
\hline
\end{tabular}


appear in the positive zone of the axis PC1, which shows that these samples were characterized by higher levels of Strecker and Maillard compounds and lower levels of lipid oxidation compounds. The PC2 axis was mainly composed of lipid oxidation derived compounds, but did not show any trend with regard to the effect of ripening time or pig feeding.

\section{CONCLUSIONS}

Ripening time had a marked effect on the volatile compounds of Iberian ham, especially on Strecker and Maillard volatile compounds whose abundances increased throughout processing. The abundance of some of these compounds (2-methylpropanal, 2methylbutanal, 2-methy-l-butanol, disulfide dimethyl, 2,6-dimethylpyrazine + dihidro-2(3H)furanone and benzenemethanol) could be used as indicators of the ripening time and, therefore, as flavour development indicators. Also, some odour-active compounds (butanoic acid, 2,6-dimethylpirazyne and 1-octen-3-ol) were more abundant in Montanera than in Pienso hams, and they could be used as indicators of the feeding system.

\section{REFERENCES}

Andrés Al, Cava R, Ruiz J. 2002. Monitoring volatile compounds during dry-cured ham ripening by solidphase microextraction coupled to a new directextraction device. J. Chromatogr. A 963, 83-88

Andrés Al, Cava R, Ventanas J, Thovar V, Ruiz J. 2004. Sensory characteristics of Iberian ham: Influence of salt content and processing conditions. Meat Sci. $\mathbf{6 8}$, 45-51.

Andrés Al, Cava R, Ventanas S, Muriel E, Ruiz J. 2007. Effect of salt content and processing conditions on volatile compounds formation throughout the ripening of Iberian ham. Eur. Food Res. Technol. 225, 677-684.

Antequera T, López-Bote C, Córdoba JJ, García C, Asensio, MA, Ventanas J, García-Regueiro JA, Díaz I. 1992. Lipid oxidative changes in the processing of Iberian pig hams. Food Chem. 45, 105-110.

Bazemore R, Goodner K, Roeseff R. 1999. Volatiles from unpasteurized and excessively heated orange juice analyzed with solid phase microxtraction and GColfactometry. J. Food Sci. 64, 800-803.

Belitz HD, Grosch W. 1992. Química de los Alimentos, $2^{2}$ edición. Ed. Acribia, Zaragoza.

Blank I, Devaud S, Fay LB, Cerny C, Steiner M, Zurbriggen B. 2001. Odor-active compounds of dry meat: Italian-type salami and Parma ham. In: Aroma active compounds in foods. Eds.: G.R. Takeoka, M.Guntert, K.H. Engel. ACS Symposium series 794, Washington, 9-20.

Brunton NP, Cronin DA, Monahan FJ, Durcan R. 2000. A comparationof solid-phase microextraction (SPME) fibres for measurement of hexanal and pentanal in cooked turkey. Food Chem. 68, 339-345.

Carrapiso Al. 2007. Effect of fat content on flavour release from sausages. Food Chem. 103, 396-403.

Carrapiso Al, Bonilla F, García C 2003a. Effect of crossbreeding and rearing system on sensory characteristics of Iberian ham. Meat Sci. 65, 623-629.
Carrapiso AI, Garcia C. 2004. Iberian ham headspace: odorants of intermuscular fat and differences with lean. J. Sci. Food Agric 84, 2047-2051.

Carrapiso Al, Garcia C. 2007. Effect of sampling conditions on the odour-active compounds of iberian ham. Cienc. Tecnol. Alimen. 5, 287-292.

Carrapiso Al, Garcia C. 2008. Effect of the Iberian pig line on dry-cured ham characteristics. Meat Sci. 80, 529534.

Carrapiso Al, Jurado A, García C. 2003b. Effect of Crossbreeding and Rearing System on Iberian Ham Volatile Compounds. Food Sci. Technol. Int. 9, 421-426.

Carrapiso Al, Jurado A, Martín L, García C. 2007. The duration of the outdoor rearing period of pigs influences Iberian ham characteristics. Irish J. Agric. Food Res. 46,102-115

Carrapiso Al, Jurado A, Timón ML, García C. 2002a. Odor-active compounds of Iberian hams with different aroma characteristics. J. Agric. Food Chem. 50, 64536458.

Carrapiso Al, Ventanas J, García C. 2002b. Characterization of the most odor-active compounds of Iberian ham headspace. J. Agric. Food Chem. 50, 1996-2000.

Cava R, Ruiz J, Ventanas J, Antequera T. 1999. Effect of $\alpha$-tocopheryl acetate supplementation and the extensive feeding of pigs on the volatile aldehydes during the maduration of Iberian ham. Food Sci. Technol. Int. 5, 235-241.

Cava R, Ventanas J, Ruiz J, Andrés Al, Antequera T. 2000a. Sensory characteristics of Iberian ham: influence of rearing system and muscle location. Food Sci. Technol Int. 6, 235-242.

Cava R, Ventanas J, Tejeda JF, Ruiz J, Antequera T. $2000 \mathrm{~b}$. Effect of free-range rearing and alphatocopherol and copper supplementation on fatty acid profiles and susceptibility to lipid oxidation of fresh meat from Iberian pigs. Food Chem. 68, 51-59.

Chevance FFV, Farmer LJ. 1999. Release of volatile odor compounds from full-fat and reduced-fat frankfurters J. Agric. Food Chem. 47, 5161-5168

Chin HW, Bernahard RA, Rosenberg M.1996. Solid phase microextraction for the cheese volatile compound analysis. J. Food Sci. 61, 1118-2641.

Elmore JS, Campo MM, Enser M, Mottram D. 2002. Effect of Lipid Composition on Meat-like Model Systems Containing Cysteine, Ribose, and Polyunsatured fatty acids. J. Agric Food Chem. 50, 1126-1132.

Elmore JS, Erbahadir MA, Mottram, DS.1997. Comparison of dynamic headspace concentration on Tenax with solid phase microextraction for the analysis of aroma volatiles. J. Agric. Food Chem. 45, 2638-2641.

Elmore JS, Mottram DS, Hierro E. 2000. Two fibre solidphase microextraction combined with gas chromatography-mass spectrometry for the analysis of volatile aroma compounds in cooked pork. J. Chromatogr. A 905, 233-240.

Flores M, Grimm CC, Toldrá FA, Spanier AM. 1997. Correlations of sensory and volatile compounds of Spanish Serrano dry-cured ham as a function of two processing times. J. Agric. Food Chem. 45, 21782186.

García C, Berdagué JL, Antequera T, López-Bote C, Córdoba JJ, Ventanas J. 1991. Volatile components of dry-cured Iberian ham. Food Chem. 41, 23-32.

García C, Martín A, Timón ML, Córdoba JJ. 2000. Microbial populations and volatile compounds in the "bone taint". Lett.Appli. Microbiol. 30, 61-66. 
Garcia-Esteban A, Ansorena D, Astiasaran I, Ruiz J. 2004. Study of the effect of different fiber coatings and extraction conditions on dry cured ham volatile compounds extracted by solid-phase microextraction (SPME). Talanta 64, 458-466.

Gianelli MP, Flores M, Toldra F. 2002. Optimisation of solid phase microextraction (SPME) for the analysis of volatile compounds in dry-cured ham. J. Sci. Food Agric. 82, 1703-1709.

Hair JF, Anderson RE, Tatham RL, Black W.C. 1998. Multivariante Data Analysis, Fifth Edition, New Jersey: Prentice Hall.

Hidalgo FJ, Zamora R. (2004). Strecker-type degradation produced by the lipid oxidation products 4,5-Epoxy-2Alkenals. Journal of Agricultural and Food Chemistry 52, 7126-7131.

Hinrichsen LL, Pedersen SB. 1995. Relationship among flavor, volatile compounds, chimical changes and microflora in Italian-type dry-cured ham during processing. J. Agric. Food Chem. 43, 2932-2940.

Jurado A, Carrapiso Al, García C, Ventanas J, Timón ML. 2002. Changes in volatile aldehydes in subcutaneous adipose tissue during the drying stage of iberian ham. $48^{\text {th }}$ ICoMST. Congress proceedings 1, 408-409.

Jurado A, Garcia C, Timon ML, Carrapiso AI. 2007. Effect of ripening time and rearing system on amino acidrelated flavour compounds of Iberian ham. Meat Sci. 75, 585-594.

Jurado A, García C, Timón ML, Carrapiso Al. In press. Improvement of dry-cured Iberian ham sensory characteristics through the use of a concentrate high in oleic acid for pig feeding. Irish J. Agric. Food Res.

Kataoka H, Lord HL, Pawliszyn J. 2000. Applications of solid-phase microextraction in food analysis (review). J. Chromatogr. A 880, 35-62.

Kondjoyan N, Berdagué JL. 1996. A compilation of relative retention indices for the analysis of aromatic compounds. Ed. Laboratoire Flaveur, Station de Reserches sur la Viande, INRA de THEIX, Saint Genes de Champanelle, France.

López MO, de la Hoz L, Cambero MI, Gallardo E, Reglero G, Ordóñez JA. 1992. Volatile compounds of dry hams form Iberian pigs. Meat Sci. 31, 267-277.

Marsili RT. 1999. Comparison of solid-phase microextraction and dinamyc headspace methods for the gas chromatographic mass spectrometric analysis of light-induced lipid oxidation products in milk. J. Chromatogr. Sci. 37, 17-23.

Meynier A, Novelli E, Chizzolini R, Zanardi E, Gandemer G. 1999. Volatile compounds of commercial Milano Salami. Meat Sci. 51, 175-183.

Mottram DS. 1998. Flavor formation in meat and meat products: a review. Food Chem. 62, 415-424.

Muriel E, Ruiz J, Ventanas J, Antequera T. 2002. Freerange rearing increases $(n-3)$ polyunsaturated fatty acids of neutral and polar lipids in swine muscles. Food Chem. 78, 219-225.
O'Sullivan MG, Byrne DV, Jensen MT, Andersen HJ, Vestergaard J. 2003. A comparison of warmed-over flavour in pork by sensory analysis, GC/MS and the electronic nose. Meat Sci. 65, 1125-1138.

Pripis-Nicaulau L, De Revel G, Bertrand A, Maujean A. 2000. Formation of flavor components by the reaction of amino acid and carbonyl compounds in mild conditions. J. Agric. Food Chem, 48, 3761-3766.

Prosen H, Zupancic-Krajl L. 1999. Solid-phase microextraction. Trends in analytical chemistry 18, 272-282.

Ramirez MR, Cava R. 2007. Volatile profiles of dry-cured meat products from different Iberian $x$ Duroc genotypes. J. Agric. Food Chem. 55, 1923-1931.

RD 1467/2007. Norma de Calidad para la carne, el jamón, la paleta y la caña de lomo ibérico. B.O.E. 3 de Noviembre de 2007, num. 264, 45087-45104.

Ruiz J, Cava R, Ventanas J, Jensen MT. 1998. Headspace solid phase microextraction for the analysis of volatiles in a meat product: Dry-cured Iberian ham. J. Agric Food Chem. 46, 4688-4694.

Ruiz J, de la Hoz L, Isabel B, Rey AI, Daza A, López-Bote CJ. 2005. Improvement of dry-cured Iberian ham quality characteristics through modifications of dietary fat composition and supplementation with vitamin $\mathrm{E}$. Food Sci. Technol. Int. 11, 327-335.

Ruiz J, García C, Muriel E, Andrés Al, Ventanas J. 2002. Influence of sensory characteristics on the acceptability of dry-cured ham. Meat Sci. 61, 347-354.

Ruiz J, Ventanas J, Cava R, Andrés Al, García C. 1999. Volatile compounds of dry-cured Iberian ham as affected by the lenght of the curing process. Meat Sci. 52, 19-27.

Ruiz J, Ventanas J, Cava R. 2001. New device for direct extraction of volatiles in solid samples using SPME. $J$. Agric. Food Chem. 49, 5115-5121.

Shahidi F. 2001. Headspace volatile aldehydes as indicators of lipid oxidation in foods. Headspace Analysis of Food and Flavor: Theory and Practice, ed. Rouseff and Cadwallader. Kluwer Academic/Plenum Publishers. New York, 113-123.

Shahidi F, Yun J, Rubin JL, Wood DF. 1987. The Hexanal content as indicatir of oxidative stability and flavour acceptability in cooked ground pork. Canadian Institute of Food Science and Technology 20, 104-106.

Timón ML, Carrapiso Al, Jurado A, Van de Lagemaat J. 2004. A study of the aroma of fried bacon and fried pork loin. J. Sci. Food Agri. 84, 825-831.

Ventanas S, Ventanas J, Tovar J, García C. and Estévez M. 2007. Extensive feeding versus oleic acid and tocopherol enriched mixed diets for the production of Iberian dry-cured hams: Effect on chemical composition, oxidative status and sensory traits. Meat Sci. 77, 246-256.

Recibido: $17 / 12 / 08$ Aceptado: 30/1/09 